\title{
High Chromium White Irons for Mining, Grinding and Materials Handling
}

Dipak Kumar Mondal*

National Institute of Technology, Durgapur, India

\section{Opinion}

Table 1: Chemical composition of some common white irons [1].

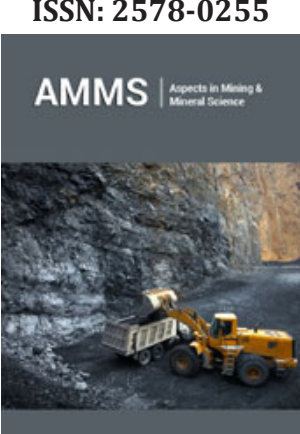

*Corresponding author: Dipak Kumar Mondal, National Institute of Technology, Durgapur, India

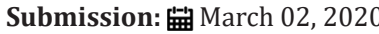

Published: 啙 March 18, 2020

Volume 4 - Issue 4

How to cite this article: Dipak Kumar Mondal. High Chromium White Irons for Mining, Grinding and Materials Handling. Aspects Min Miner Sci.4(4) AMMS.000594.2020.

DOI: 10.31031/AMMS.2020.04.000594

Copyright@ Dipak Kumar Mondal, This article is distributed under the terms of the Creative Commons Attribution 4.0 International License, which permits unrestricted use and redistribution provided that the original author and source are credited.

\begin{tabular}{|c|c|c|c|c|c|c|c|c|c|}
\hline \multicolumn{10}{|c|}{ Elements, wt.\% } \\
\hline Type & $\mathbf{C}$ & $\mathbf{M n}$ & $\mathbf{S i}$ & $\mathbf{N i}$ & $\mathbf{C r}$ & $\mathbf{M o}$ & $\mathbf{P}$ & $\mathbf{S}$ & $\mathbf{C u}$ \\
\hline $12 \mathrm{Cr}$ & $2.0-3.3$ & 2.0 & 1.5 & 2.5 & $11.0-14.0$ & 3.0 & 0.1 & 0.06 & 1.2 \\
\hline $15 \mathrm{Cr}-\mathrm{Mo}$ & $2.0-3.3$ & 2.0 & 1.5 & 2.5 & $14.0-18.0$ & 3.0 & 0.1 & 0.06 & 1.2 \\
\hline $20 \mathrm{Cr}-\mathrm{Mo}$ & $2.0-3.3$ & 2.0 & $1.0-2.2$ & 2.5 & $18.0-23.0$ & 3.0 & 0.1 & 0.06 & 1.2 \\
\hline $25 \mathrm{Cr}$ & $2.3-3.3$ & 2.0 & 1.5 & 2.5 & $23.0-30.0$ & 3.0 & 0.1 & 0.06 & 1.2 \\
\hline
\end{tabular}

High chromium white irons of hypoeutectic grade (Table 1) are largely used in mining, grinding and materials handling where their performance happens to be a function of not only the microstructure and properties, but also the abrasive wear resistance and ability to withstand impact. So, this short review explores the role of microstructure and properties, namely, hardness and impact toughness towards building better wear performance involving combined action of abrasion and impact. The as-cast microstructure of high chromium white irons consists of primary austenite dendrites and inter-dendritic eutectic of $\mathrm{M}_{7} \mathrm{C}_{3}$ carbides ('M' stands for metallic species including iron and chromium) and partially transformed austenite. Although the chromium content of high chromium white irons appears between 12 and $30 \%$ (by wt.), the majority of this is combined with carbon to form carbides and quite a low content is retained in the austenite matrix. So, molybdenum along with nickel and copper is added to high chromium white irons in excess of $1.0 \%$ (by wt.) to maintain hardenability of the austenite matrix [1]. The eutectic carbides usually assume discontinuous pattern of $\mathrm{M}_{7} \mathrm{C}_{3}$ rods, each having hollow core filled with matrix material and exhibiting hexagonal crosssection [2]. Duplex carbides may also occur as $\mathrm{M}_{7} \mathrm{C}_{3}$ encased with a layer of $\mathrm{M}_{3} \mathrm{C}$ following solid state diffusion during post solidification cooling. To improve impact toughness in chromium white irons, boron addition or use of rare earth has been suggested aiming to refine the eutectic carbides. Simultaneously, attempts are made to modify eutectic structure through alloying but with limited success. Further, to improve wear performance under impact, ascast chromium white irons are subjected to 2-6h holding at temperatures ranging between 900 and $1100^{\circ} \mathrm{C}$ aiming mainly to destabilize [3-6] the metastable austenite. Destabilization at lower temperatures $\left(900-950^{\circ} \mathrm{C}\right)$ gives rise extensive precipitation of secondary carbides, reducing drastically the carbon content of the austenite and transforming it to low carbon martensite with poor hardness. On the other hand, at higher destabilization temperature $\left(>1000^{\circ} \mathrm{C}\right.$ ), carbon solubility being higher in the austenite, there is limited precipitation of secondary carbides and on post-destabilization cooling the high carbon austenite transforms to martensite with large content of retained austenite usually detrimental for matrix hard ness. In both cases, moderate cooling (air cooling) after destabilization provides greater hardness of the alloy attributing this to additional precipitation of secondary carbides during cooling cycle; however, cooling at a very slow rate (furnace cooling) leads to the formation of pearlitic matrix impairing the hardness. To reduce the retained austenite content appearing with martensite following destabilization treatment, careful control of destabilizing condition 
using subcritical treatment followed by cryogenic treatment below $\mathrm{M}_{\mathrm{f}}$ is suggested [7]. Alternatively, the use of multiple quench and subcritical treatment has been noticed to be beneficial by reducing the period of destabilization [8].

The bulk hardness and microhardness of the alloys subjected to destabilization treatment at various temperatures are much higher than those of as-cast condition. For example, the as-cast bulk hardness of HRC 52 rises to HRC 69 after destabilizing 18Cr-1Mo2.6C white iron at $1000{ }^{\circ} \mathrm{C}$, attributing this to a maximum volume fraction of carbides and martensite [9]. A decrease in hardness of the matrix is observed with increasing destabilization temperature following increase in retained austenite content and coarsening of secondary carbides. Subsequently, the abrasive wear resistance of high chromium white irons being an ultimate requirement during service, is also noticed to improve following destabilization treatment of as-cast alloys. Thus, a destabilized microstructure issuing a suitable combination of martensite, retained austenite and carbide phases can build-up wear performance, while refinement of massive eutectic carbides appears to provide some additional favor. In this context, the recently developed idea of cyclic destabilization [10] for shorter duration (0.66h) at both low and high temperatures certainly deserves attention by issuing a combination of martensite and retained austenite along with spheroidized eutectic carbides, quite suitable to raise the hardness up to HV 900 and impact toughness to $12 \mathrm{~J}$ in association with minimum wear loss.

\section{References}

1. Tabrett CP, Sare IR, Ghomaschi MR (1996) Microstructure-property relationships in high chromium white iron alloys. Int Mater Rev 41(2): 59-82.
2. Laird II G (1993) Trans AFS 101: 497-504.

3. Jacuinde AB, Arias L, Hernandez B (2003) Kinetics of secondary carbides precipitation in a high-chromium white iron. J Mater Eng Perform 12(4): 371-382.

4. Hinckley B, Dolman KF, Wuhrer R, Yeung W, Ray A (2008) Sem investigation of heat treated high-chromium cast irons. Mater Forum 32: $55-71$.

5. Karantzalis AE, Lekatou A, Diavati E (2009) effect of destabilization heat treatments on the microstructure of high-chromium cast iron: A microscopy examination approach. J Mater Eng Perform 18(8): 1078 -1085 .

6. Efremenko V, Shimizu K, Chabak Y (2013) Effect of destabilizing heat treatment on solid-state phase transformation in high-chromium cast irons. Metall Mater Trans A 44: 5434-5446.

7. Wang J, Xiong J, Fan H, Yong HS, Liu HH, et al. (2009) Effects of high temperature and cryogenic treatment on the microstructure and abrasion resistance of a high chromium cast iron. J Mater Process Tech 209(7): 3236-3240.

8. Jia X, Hao Q, Zuo X, Chen N, Rong Y (2014) High hardness and toughness of white cast iron: The proposal of a novel process. Mater Sci Eng A 618: 96-103.

9. Gasan H, Erturk F (2013) Effects of a destabilization heat treatment on the microstructure and abrasive wear behavior of high-chromium white cast iron investigated using different characterization techniques. Metallurgical and Materials Transactions A 44: 4993-5005.

10. Mandal SS, Ghosh KS, Mondal DK (2018) Microstructure, hardness, toughness and abrasive wear resistance of 16 wt.\% chromium white iron after continuous and cyclic destabilization treatment. Int J Cast Met Res 31: 3177-3192.

For possible submissions Click below: 